\title{
Characterization of Physical and Chemical Properties of Collagen Golden Apple Snail (Pomacea canaliculata)
}

\author{
$1^{\text {st }}$ Aung Sumbono ${ }^{1}, 2^{\text {nd }}$ Dheni Rossarie ${ }^{2}$ \\ \{aungsumbono@gmail.com ${ }^{1}$ \} \\ Faculty of Science And Technology Universitas Pendidikan Muhammadiyah Sorong, West Papua, \\ Indonesia ${ }^{1,2}$
}

\begin{abstract}
This research will examine the physical and chemical properties of collagen gold snail (Pomacea canaliculata) from agricultural areas in West Papua. Collagen is obtained from the isolation of golden snail meat using the Gomez-gullien method. The solvents used are acid solvents namely acetic acid, phosphoric acid and hydrochloric acid. The concentration of solvent is $2.5 \%, 5 \%$ and $10 \%$. The isolation characteristics of collagen were tested to determine the physical and chemical physicochemical properties with Fourier Transform Infrared (FTIR), viscometer, Differential Scanning Calorimetry (DSC), Thermogravimetric Analyzer (TGA) Scanning Electron Microscope (SEM), the value of the percentage yield, water content, mass analysis relative molecules, Analysis of $\mathrm{pH}$, tensile strength (TS) and elongation at break (E). The results of the analysis of the characteristics of collagen isolation results showed the amide absorption wave number of functional group markers of collagen. The solvent used Affects the amide III absorption wave number as a crosslinking marker. The results showed a relative molecular weight of 18455.77 - 231950,49 gram mol-1. The highest yield was obtained from collagen soaked with sulfuric acid, which was $11.91 \%$. The analysis shows physical properties such as $\mathrm{pH}$, relative molecular mass, glass transition temperature, microstructure, melting temperature, thermal degredation temperature, and weight loss due to collagen thermal degredation influenced by the type of solvent used. The value of TS and elongation at break $(\mathrm{E})$ is influenced by the type of solvent.
\end{abstract}

Keywords: collagen, golden snail, physical properties, chemical properties

\section{Introduction}

Collagen is a soluble polypeptide derived from collagen, which is the main constituent of skin, bone, and connective tissue of animals. Collagen is obtained through partial hydrolysis of collagen. When collagen is treated with acids or bases and followed by heat, the fibrous structure of collagen is broken down irreversibly resulting in collagen (Zhou and Regenstein., 2004, 2005). The rate of conversion of collagen to collagen is related to the degree of damage from pre-treatment and extraction processes, $\mathrm{pH}$, temperature and time of extraction (Johnston-Bank, 1990). Collagen is one of the most widely used ingredients in the pharmaceutical and food industries. Mammalian skin and bones are used as raw material for the collagen industry. The presence of bovine spongiform encephalopathy (BSE), transmissible spongiform encephalopathy (TSE) and foot and mouth disease (FMD) cause anxiety among collagen users and collagen products derived from these mammals 
(Jongjareonrak et al., 2005). Apart from the medical side, Muslims and Jews are prohibited from using material from pigs and Hindus are prohibited from using material from cows (Kasankala et al., 2007).

Now scientists have found that the skin, bones, fins and cartilage of freshwater fish and marine fish (Shen et al., 2007) can be used as a source of new collagen. Shen et al., (2007) and Mizuta et al., (2002) state that shellfish and pearl oysters can also be used as alternative raw materials for collagen. The findings related to new sources of collagen raw material are not supported by many research reports on new sources of collagen, so the information is very lacking. Melnick (1958) once examined the differences in collagen from the mollusca family animals. Proteins in molluscs have also been studied in terms of biology by Blankenship (1984) and Wessel (1991).

Gold snail / golden apple snail (Pomacea canaliculata Lamarck), including freshwater snails, with rounded golden yellow conical shells. According to Lamarck the first golden snail came from Guadeloupe, but there is another explanation which states that the golden snail came from the Parana River (Parana). In Brazil, then golden snails are found in the vast flat of the Pantanal; in Bolivia, in swamps and hot springs. Gold snails are equipped with gills and parasites such as respiratory organs, gold snails are able to adapt to life in wet and dry land such as seasonal swamp habitat or rice fields. The golden snail quickly spreads through natural waterways and irrigation channels and finally attacks the rice fields (Halwart, 1994). International concerns about snail mas (Pomacea canaliculata) (Lamarck, 1822) have greatly increased when they become very serious pests in agriculture in Asia including Indonesia (Estebenet, 2002). Research on golden snails is still limited to their growth, survival, reproduction, and dependence on temperature distribution.

The physical and chemical properties of collagen from golden snails (Pomacea canaliculata) have not been studied systematically to determine the possibility of industrial application as a material of higher value. Therefore, golden snails were chosen to be isolated and examined to determine the physical and chemical properties of collagen.

\section{Method}

The method of implementation in this program is to analyze the physical and chemical properties of collagen gold snail (Pomacea canaliculata), by conducting measured experiments. The stages in this research are:

Equipment used for collagen isolation in this study include: Heaters, thermometers, 1000 $\mathrm{ml}$ glass beakers, measuring pipettes, measuring flasks (pyrex production), analytical balance, knives, gauze, stirrers, ovens, tongs, plastic cups, small bottles , waterbath, sheet glass, micro hair injection, heater, extractor, dryer and $\mathrm{pH}$ meter.

The equipment used for characterization are; petri dish (pyrex production), stirrer, Differential Scanning Calorimetry (DSC), Thermogravimetric Analysis (TGA), Ostwald viscometer (pyrex production), Transform Infrared Spectroscopy (FTIR) and Scanning Electron Microscope (SEM), and tensile test.

The materials used in this study include: snail mas (Pomacea canaliculata) planned to be taken from agricultural sites in West Papua, $\mathrm{HCl}, \mathrm{H} 3 \mathrm{PO} 4, \mathrm{CH} 3 \mathrm{COOH}$, collagen bovine (Type B, G9382), porcine collagen (Type A, G2500), glutaraldehyde 2.5\% (v/v), phosphate buffer $0.2 \mathrm{M}(\mathrm{pH} 7.2)$, ethanol $50 \%(\mathrm{v} / \mathrm{v})$ and Aquabides. All chemicals used are standardized in pro analysis (PA). 
Fresh golden snails (Pomacea canaliculata) weighing between 100-150 grams each are taken from Indonesia's West Papua agricultural area. Meat is separated from the shell in the laboratory. Golden conch meat is cleaned with tap water, and packaged in plastic, then stored in a refrigerator at $-5 \mathrm{oC}$. The rendemen plastic is packed in a special box to prepare sample material for several repetitions. Repetition of the study is based on the number of solvents, with each solvent being carried out 10 times.

Isolation of collagen is divided into 4 main stages, namely: (1) Isolation of golden snail collagen by treating hydrochloric acid, (2) Isolation of golden snail collagen by treatment of phosphoric acid, (3) Isolation of golden snail collagen by treatment of acetic acid. Isolation of collagen is divided into 3 acid variations, namely: (1) hydrochloric acid, (2) phosphoric acid, (3) acetic acid. Acid concentrations are divided into 3 concentration variations namely $2.5 \%$, $5 \%$ and $10 \%$. The immersion time for demineralization is divided into 12 hours, 24 hours and 36 hours. Variation of concentration and immersion was repeated 10 times.

The formation of jelly and the making of the film layer is done by filtering the filtered results from the extraction into a plastic container, then put it in a cooler or frezer with a temperature of $5 \mathrm{oC}$. The work steps of collagen isolation are shown in Scheme 3.

The film layer is made by laying the filter uniformly (Schema 3; after extracting the filter) on a sheet of glass measuring $10 \times 10 \mathrm{~cm}$ that has been given a border on each side. Next, it is dried with hair drayer to dry and form a thin layer. The thin layer is prepared for mechanical testing. Thick layers are made such that thick layers are obtained which are needed for some analytical instruments.

Yield analysis is carried out to determine the value of the percentage of yield (AOAC method, 1995), Moisture content (AOAC method, 1995). analysis of relative molecular mass (Zhang et al. 2007) where molecular weight is calculated by the MHS equation formula (Mark-Houwink-Sakurada, 1987), pH analysis (BSI 757, 1975). FTIR analysis (Liu et al, 2009). Differential scanning calorimeter (DSC) analysis and Thermogravimetric Analysis (TGA) initial scan was carried out at $30 \mathrm{oC}$ and ended at $600 \mathrm{oC}$ (Nuthong et al. 2009), SEM analysis (Soottawat Benjakul, et al, 2014), tensile strength (TS) ) and elongation at break (E) are measured according to the ASTM Standard test method for tensile properties of thin plastic sheeting using a universal testing machine (Instron 4465).

\section{Discussion}

Isolation of golden snail collagen with a concentration of $5 \%$ shows the longer soaking, the more yield yield percentage. This is shown in Figure 1. The yield is even greater because $\mathrm{H}+$ ions from solvents play a role to break hydrogen bonds so that the collagen coil is stretched (Montero et al., 1990; Norland, 1990; Stainsby, 1987; Gustavson, 1956; Xiong, 1997). The increasingly tenuous collagen coil results in optimal thermal distribution at the time of extraction so that more peptide bonds are broken. Breaking more peptide bonds results in more yield. In addition, the more stretched collagen will get a longer chain of collagen biopolymer. 

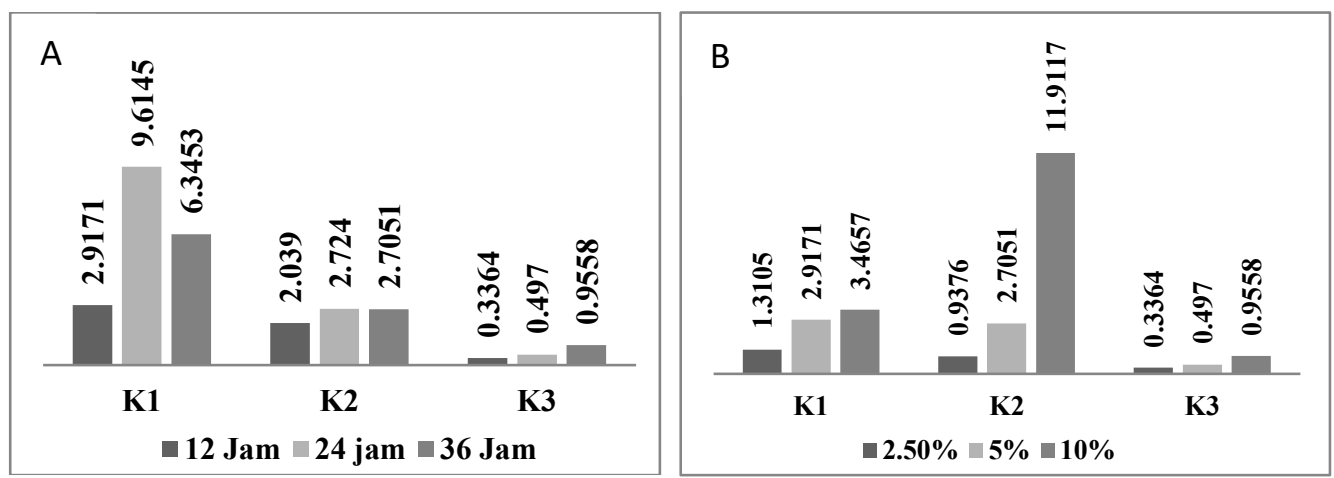

Figure 1. (A) Relationship of the percentage of bone gelatin yield to the time of immersion (B) The relationship of the percentage of bone gelatin yield to solvent concentration

At the same time immersion, isolation of the highest acidity collagen (hydrochloric acid) obtained the greatest yield. Hydrochloric acid is easy to break hydrogen bonds in collagen because $\mathrm{Cl}^{-}$anions are more electronegative than $\mathrm{PO} 43-$ and $\mathrm{CH}_{3} \mathrm{COO}^{-}$. The more electronegative $\mathrm{Cl}^{-}$ions cause greater solvents to momendipol so that the attractive force towards positively charged ions is greater. The greater the tensile force the greater the ability to disrupt and break the bonds of hydrogen intra and inter molecules in collagen (Barret and Elmore, 2004). The more hydrogen bonds are cut off, the more the collagen coil is stretched so that a higher yield is obtained. However, the difference is shown by the yield of collagen hydrochloric acid (K1) decreases after 24 hours. Decrease in yield of K1 due to excessive collagen degradation (Jamilah and Harvinder, 2002) so that part of the collagen biopolymer chains are formed short or collagen monomers that are soluble in the solvent. Short chain collagen or collagen monomers cannot be extracted.

The higher the concentration of the solvent the higher the yield of collagen. This is shown in Figure 4.3. This increase in yield is due to the increasing number of $\mathrm{H}+$ ions from solvents that act as breakers of hydrogen bonds (Montero et al., 1990; Norland, 1990; Stainsby, 1987; Gustavson, 1956; Xiong, 1997). The more H+ ions that cause the broken collagen hydrogen bonds will be more and more broken, so that the higher the collagen stretching and the easier thermal break of the peptide bonds.

It was also shown that the greater the acidity the higher the yield of collagen. This is due to the increasing number of solvent $\mathrm{H}+$ ions which break hydrogen bonds in collagen. However, a higher range of collagen increase is shown by phosphoric acid (K2) solvent collagen (from $0.94 \%$ to $2.71 \%$ and $2.71 \%$ to $11.91 \%$ ) compared to other acid solvents. This is a result of the phosphoric acid solvent which is a polyprotic acid (has three $\mathrm{H}+$ ions) so that more hydrogen bonds in the collagen are disturbed and broken. Based on this fact shows that the number of $\mathrm{H}+$ ions also plays a role in determining the amount of broken collagen hydrogen bonds.

FTIR analysis was carried out to show that collagen had formed. This is indicated by the absorption of wave numbers 1636-1661 cm-1 amide A marker, $1600-1700 \mathrm{~cm}-1$ amide I marker, 1650-1580 cm-1 amide II marker (Renugopalakrishnan et al, 1989) and 1200-1300 cm- 1 amide III marker (Friess and Lee, 1996). FTIR spectra are shown in Figures 2. In general, collagen FTIR spectra showed similar uptake in amide region wave numbers from collagen reported by Yan et al (2008). The peaks of wave collagen uptake of collagen markers 
from the snail collagen FTIR spectra are summarized in table 1. The snail collagen FTIR spectra shows the amide I peak as a stretching marker $\mathrm{C}=\mathrm{O}$ combined with contributions from CN stretching, CCN deformation and NH bending (Bandekar, 1992 ; Lavialle et al., 1982) of collagen gold snails. The amide I peak with a characteristic frequency at 1600-1700 $\mathrm{cm}-1$ is also a sensitive marker of the secondary structure of the peptide (Surewicz and Mantsch, 1988; Yakimets et al 2005), stretching of the carbonyl group along the main polypeptide sequence and helical state (Payne and Helices) Veis, 1988; George and Veis, 1991).

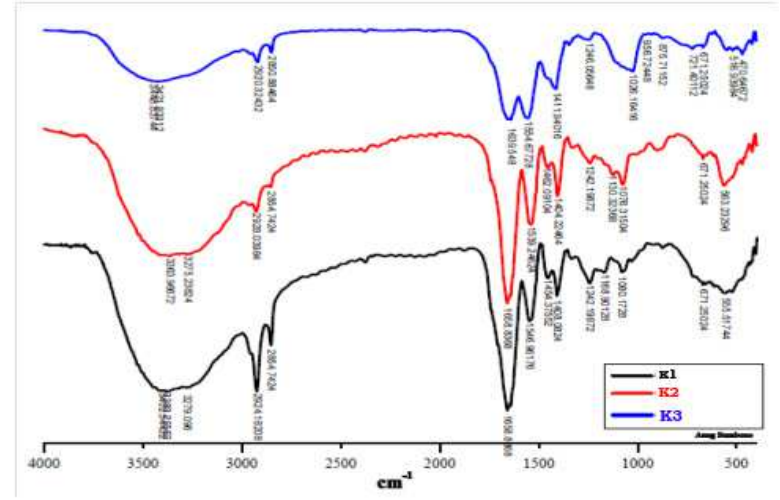

Figures 2. FTIR Spectra collagen

The FTIR spectra data show the peak wave number of amide II. These wave numbers prove stretching C-N (1335-1250 $\left.\mathrm{cm}^{-1}\right)$ and N-H deformation $(1650-1580 \mathrm{~cm}-1)$ of the peptide group (Renugopalakrishnan et al, 1989). Amide III region $\left(1200-1300 \mathrm{~cm}^{-1}\right.$ ) of red snapper has been shown in the FTIR spectra results. The peak of the amide III region proves the disturbance in the collagen molecule and is related to the loss of the triple helical state (Friess and Lee, 1996). Absorption in this region is due to vibrations of C-O carbohydrates (Jackson et al, 1995). Carbohydrates in collagen are related to collagen glycation (Bailey et al, 1998). Amide III is also associated with NH bending combined with CN stretching (Pati et al, 2010).

In addition, amide A from red snapper has also been shown in the FTIR spectra as a marker of N-H group stretching. Typically, free $\mathrm{N}-\mathrm{H}$ stretching vibrations (amide A) occur in the range $3400-3440 \mathrm{~cm}^{-1}$. When the peptide $\mathrm{N}-\mathrm{H}$ group is involved in hydrogen bonds, the position shifts to a lower frequency (Doyle et al., 1975). Amide B wave numbers as markers of asymmetrical stretching vibrations of $=\mathrm{C}-\mathrm{H}$ and $-\mathrm{NH}^{+3}$ have been shown in red snapper collagen FTIR spectra. All collagen samples have an amide B peak which shows the interaction of $-\mathrm{NH}_{3}$ groups between the peptide chains. The shifts and differences in amide wave numbers are affected by differences in treatment and extraction time (Ahmad and Benjakul, 2011). FTIR spectra Red snapper collagen has also shown the presence of peptide chains as a marker of C-O vibrations. C-O vibrations occur in wave numbers $1000-1100 \mathrm{~cm}^{-1}$ (Jackson et al, 1995). Thus, it can be concluded that the secondary structure as a collagen marker is owned by golden snail collagen. FTIR spectra results show similarities to mammalian collagen spectra namely the presence of $\mathrm{O}-\mathrm{H}, \mathrm{C}-\mathrm{H}, \mathrm{C}=\mathrm{O}, \mathrm{N}-\mathrm{H}$ and $\mathrm{C}-\mathrm{H}$ aromatic function groups (Norziah, 2009; Prystupa and Donald, 1996).

Crosslinking occurs because of hydrogen bonds in the triple helices and is a characteristic of collagen molecules (Nijenhuis, 1997). Collagen is a combination of several different compounds namely $\alpha$-chains (one polymer chain), $\beta$-chains (two covalent $\alpha$-chains) 
and $\gamma$ chains (three covalent $\alpha$-chains) (Papon et al., 2007). Crosslinking that occurs in collagen can be identified by FTIR (Friess and Lee, 1996). Crosslinking is evidenced by the shift in the peak of the amide wave III (1200-1300 $\left.\mathrm{cm}^{-1}\right)$ which shows interference in the collagen molecule and is related to the reduced state of the triple helical collagen (Friess and Lee, 1996).

The peak of amide III collagen that is at wave numbers $1242 \mathrm{~cm}^{-1}, 1242 \mathrm{~cm}^{-1}$ and 1246 $\mathrm{cm}^{-1}$ respectively for hydrochloric acid, phosphoric acid and acetic acid solvents. FTIR spectra show the wave numbers for amide III are relatively the same.

The peak of amide III collagen acetic acid appears at a greater wave number than other acid solvents. This shows that the acetic acid solvent is less disruptive to the crosslinking of collagen and the collagen obtained still has a strong triple helix compared to other solvents. Acetic acid solvents are less able to damage the crosslinking hydrogen bonds that form collagen so that the resulting collagen still contains a lot of triple helices. Amide III peaks will shift to smaller wave numbers if the disruption of the hydrogen bonds that form crosslinking on collagen molecules is getting bigger and the triple helical state is getting lost.

The peak of the wave number shifts to a smaller number than the peak of amide III that is owned is influenced by the role of the $\mathrm{H}+$ ion breaking hydrogen bonds in the triple helical collagen. The more hydrogen bonds that form the triple helices are broken, the more triple helical collagen is lost, so that the absorption of amide III wave numbers is shifted to smaller numbers. The new hydrogen bonds formed by the solvent with the component amino acid collagen cause the distance between molecules is still short and allows the triple helix to form again. The shift of the peak wave number of the amide III markers of each solvent due to the degree of ability to break hydrogen bonds in collagen so that the collagen obtained has a residual hydrogen bond that forms a triple helical bond (Bailey and Light, 1989; Ward and Court, 1977)

The results of SEM display shown in Figure 3. of collagen show differences. Pores of 2 $\mu \mathrm{m}-10 \mu \mathrm{m}$ diameter are shown in the morphological display of collagen microstructures. Microstructure morphology is more dense and has an aggregate. The results of SEM display analysis of collagen will show differences in structure due to differences in the $\mathrm{pH}$ of the initial treatment for example from pig collagen that has been researched by Haugstad and Gladfelter (1993).

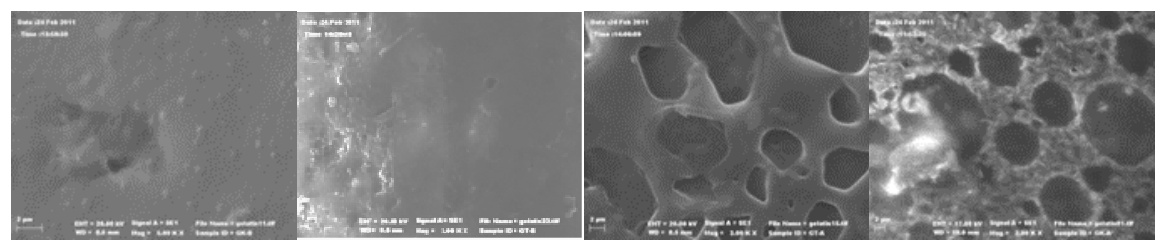

Figure 3. Morphology microstructure of collagen

The largest molecular mass (Table 1) is owned by K1. The relative molecular mass is in the range between 18455.77 - 231950.49 gram mol-1. This value is almost the same as the molecular mass value of mammalian collagen which is $80-250 \mathrm{kDa}$ (Poppe, 1997), and close to the average relative molecular mass of commercial collagen in the range between 20000 70000 grams mol-1 (Main, 1997). 
Table 1. Characteristics pf collagen

\begin{tabular}{|c|c|c|c|c|c|}
\hline \multirow{2}{*}{\multicolumn{3}{|c|}{ Characteristics }} & \multicolumn{3}{|c|}{ Sample } \\
\hline & & & K1 & $\mathrm{K} 2$ & K3 \\
\hline \multirow{2}{*}{\multicolumn{3}{|c|}{$\begin{array}{c}\text { Mass Molecul Relative } \\
\mathrm{pH}\end{array}$}} & 88899,2864 & 24019,6755 & 21002,7761 \\
\hline & & & 6,02 & 6,44 & 6,98 \\
\hline \multicolumn{3}{|c|}{ Water Content } & $9,60 \%$ & $5,47 \%$ & $14,67 \%$ \\
\hline \multicolumn{3}{|c|}{$\mathrm{T}_{\mathrm{g}}\left({ }^{\mathrm{O}} \mathrm{c}\right)$} & 42,3 & 47,8 & 47,0 \\
\hline \multicolumn{3}{|c|}{$\mathrm{T}_{\mathrm{m}}\left({ }^{\mathrm{O}} \mathrm{c}\right)$} & 78,3 & 82,5 & 78,6 \\
\hline \multicolumn{3}{|c|}{ Ash Levels (\%) } & 41,07 & 55,36 & 40,01 \\
\hline \multirow{8}{*}{ DEGRADATION } & STAGE & ${ }^{\circ} \mathrm{C}$ & $<130$ & $<108$ & $<115$ \\
\hline & (1) & $(\%)$ & 3,93 & 8,32 & 14,41 \\
\hline & STAGE & ${ }^{\circ} \mathrm{C}$ & 130 & 108 & 115 \\
\hline & (2) & $(\%)$ & 7,23 & 48,35 & 38,50 \\
\hline & STAGE & ${ }^{\circ} \mathrm{C}$ & 185 & 284 & 308 \\
\hline & (3) & $(\%)$ & 72,08 & 29,94 & 32,38 \\
\hline & STAGE & ${ }^{\circ} \mathrm{C}$ & 391 & 401 & 423 \\
\hline & (4) & $(\%)$ & 16,74 & 13,37 & 14,70 \\
\hline
\end{tabular}

The data obtained shows that the stronger the acidity level of the solvent, the greater the relative molecular mass of bone collagen. This relates to hydrogen bonds being broken due to the contribution of $\mathrm{H}^{+}$capability (Johnston-Banks, 1990; Bailey and Light, 1989; Karim and Bhat, 2009) so that different collagen stretches and chain lengths broken during extraction also differ. The relative molecular weight in this study refers to calculations with the MarkHouwink-Sakurada equation and the value of collagen $\alpha$ ranges from 0.45 to 0.885 (Veis, 1964). The constant value (K) used in the calculations in this study refers to calf skin collagen of $1.66 \times 10-5 \mathrm{ml} . \mathrm{g}^{-1}$ (K values and bone or fish skin $\alpha$ have not been reported) assuming the features and characteristics typical of collagen is owned by all collagen alike although the sources are different (Balian and Bowes, 1977).

The $\mathrm{pH}$ data of the collagen solution showed no correlation with the origin of the collagen source. However, there is a correlation shown on the solvent used in the immersion prior to collagen extraction to the $\mathrm{pH}$ of the resulting collagen solution. Collagen $\mathrm{pH}$ is 6.02 7.00 (Table 1). Collagen water content is calculated based on the first stage weight loss on the TGA thermogram as conducted by Nuthong et al (2009) and Langmaier et al (2008). The TGA thermogram showed that the highest water content was obtained from hydrochloric acid solvent collagen which was $3.93 \%$ and the largest was obtained from acetic acid collagen which was $14.41 \%$. The water content of collagen is influenced by several factors namely solvent, the origin of the collagen source and the drying and storage process before being analyzed with DSC instruments. Collagen water content in this study meets the standards of commercial collagen and collagen standards according to the Indonesian National Standard (SNI) which is $16 \%$.

Ash content was obtained from the calculation of the percentage of the remaining weight loss after a TGA scan at $600{ }^{\circ} \mathrm{C}$ to the initial weight (Table 1). The percentage of collagen ash content of each solvent is different. This difference is due to differences in the structure and length of the collagen biopolymer chains (Montero and Gomez-Guillen, 2000; Zhou and Regenstein, 2004).

The greater the acidity of the solvent, the greater the ash content from collagen. This is due to the length of the collagen yield chain owned is also getting longer. However, K1 ash content is smaller than $\mathrm{K} 2$. The cause of deviation of $\mathrm{K} 1$ ash content data is the impact of the process due to over degradation (Jamilah and Harvinder, 2002). 
The glass transition temperature and melting point of collagen are summarized in Table. 1. The results of a DSC scan of collagen are shown in Fig. 4. The glass transition temperature and melting point $\mathrm{K} 1$ lower than $\mathrm{K} 2$ and $\mathrm{K} 3$ are due to differences in crosslinking or uncrosslinking owned by collagen (Patil et al., 2000). This proves that hydrochloric acid collagen solvents have less crosslinking than collagen phosphoric acid and acetic acid solvents so that at low temperatures it is sufficient to produce a glass transition state and collagen melting.

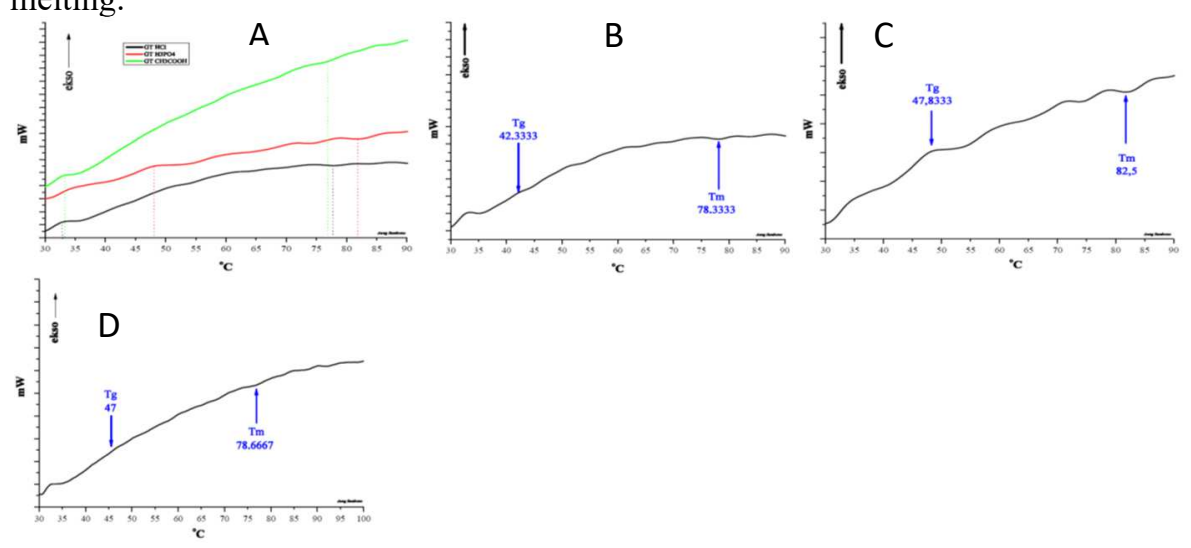

Figure 4. DSC GTA thermogram (A) Combined, (B) K1, (C) K2 and (D) K3.

However, the K2 melting temperature is higher than expected due to impurities. The reason is reinforced by the appearance of a more coarse thermogram. Impurities are able to withstand thermal, so that more thermal is needed to reach the melting state of K2 (Table 2).

The TGA thermogram (Fig. 5) shows the four main stages of degradation caused by a rise in temperature $(\Delta \mathrm{Td})$. An increase in temperature $(\Delta \mathrm{Td})$ results in a decrease in cumulative weight $(\Delta \mathrm{w})$. The stages of thermal degredation are: (1) The first stage is that the weight loss occurs due to the release of adsorbed free water and water bound to the sample (Nuthong et al., 2009; Langmaier et al., 2008). (2) The second stage of weight reduction is related to the release of structural water bonds (Burdygina et al. 1976), proteins with low molecular weight fractions and the occurrence of collagen chemical damage. At this stage also occurs the breaking of hydrogen bonds that act as forming crosslinking in collagen (Barreto et al., 2003). (3) The third stage of degradation is the stage of collagen macromolecular fragmentation (Pati et al., 2010) and (4) The fourth stage of collagen thermal degradation is the process of ignition and main decomposition due to the formation of gas elements from collagen samples (Pati et al., 2010). 

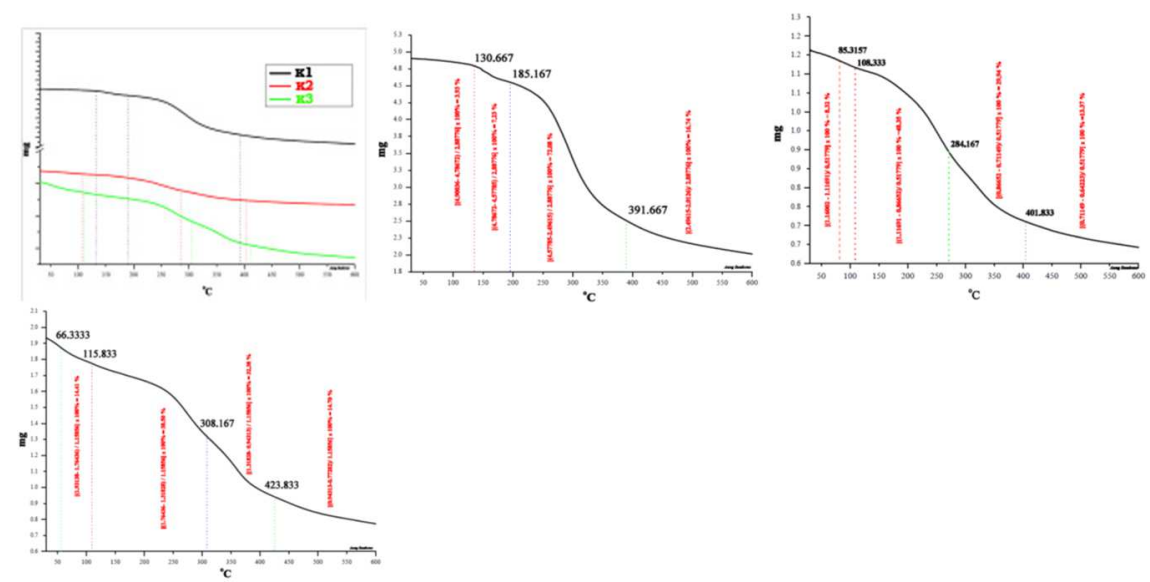

Figure 5. TGA thermogram from collagen, (A) Combined, (B) K1, (C) K2 and (D) K3.

First stage weight loss of collagen shows that the higher the acidity value, the smaller weight reduction will be obtained. This decrease is caused by the release of water (Nuthong et al., 2009; Langmaier et al., 2008). This shows that the higher the acidity of the solvent, the less hydroscopic the collagen is. In the second step, it was shown that the weight loss of collagen was different for each solvent. This is a result of each collagen having the amount of crosslinking and the amount of short chain collagen polymers that can still be extracted differently (Barreto et al., 2003; Burdygina et al. 1975). Collagen which lack crosslinking will be degraded faster by thermal. Whereas collagen which lacks a short chain of amino acid chains will result in smaller weight loss. The smallest second stage weight loss is shown by $\mathrm{K} 1$. K1 has a number of short amino acid chains due to hydrochloric acid solvents being able to break collagen peptide bonds so that some of the amino acid chains produced are very short chains or even amino acid monomers that can be dissolved in the solvent before the extraction process.

In the third stage, the greatest weight reduction is shown by $\mathrm{K} 1$ while the smallest is shown by K2. This shows that K1 has more amino acid polymers with greater molecular mass compared to other solvent collagen (Pati et al., 2010). Collagen with a relatively large molecular mass of $\mathrm{K} 1$ is more due to the ability of hydrochloric acid to break more hydrogen bonds so that greater collagen stretching is obtained compared to other solvents. Large stretches of collagen make it easy for thermal and thermal distribution to reach the inner collagen layer and produce collagen which has a greater molecular mass (Barreto et al., 2003). The fourth stage shows that each solvent has a different weight loss. Different weight loss due to the amount of gas released is different. The difference in the amount of gas-forming in each sample due to differences in structure and composition of the different collagen amino acid chains (Pati et al., 2010).

The results of the tensile strength test (TS) in Table 2 show that the solvent type treatment significantly affected TS. This is because adding the type of solution gives more affinity to the higher number of hydrogen bonds formed on the film. This is consistent with what has been reported by Al-Hassan and Norziah, (2012) and Polnaya et al., (2012). Elongation at break (EAB) EAB Table 2 shows that the type of solvent significantly influences $\mathrm{EAB}$, while the type of solvent has no significant effect. EAB increases with increasing concentration. Increasing the concentration of agar in the film solution will increase 
the water holding capacity thereby increasing the EAB. This is consistent and consistent with Murdinah et al. (2007).

Table 2. TS and EAB collagen data

\begin{tabular}{lccccccccc}
\hline & & $\mathrm{K} 1$ & & & $\mathrm{~K} 2$ & & \multicolumn{2}{c}{$\mathrm{K} 3$} \\
& $2.5 \%$ & $5 \%$ & $10 \%$ & $2.5 \%$ & $5 \%$ & $10 \%$ & $2.5 \%$ & $5 \%$ & $10 \%$ \\
\hline TS (MPa) & 22.4 & 23.8 & 24.1 & 34.6 & 36.1 & 37.9 & 15.3 & 15.3 & 15.3 \\
EAB (\%) & 15.3 & 15.4 & 15.8 & 22.6 & 23.2 & 24.1 & 27.7 & 28.2 & 29.1 \\
\hline
\end{tabular}

\section{Conclusion}

The results of the analysis of the characteristics of collagen isolation results showed the amide absorption wave number of functional group markers of collagen. The solvent used Affects the amide III absorption wave number as a crosslinking marker. The results showed a relative molecular weight of 18455.77 - 231950.49 gram mol-1. The highest yield was obtained from collagen soaked with sulfuric acid, which was $11.91 \%$. The analysis shows physical properties such as $\mathrm{pH}$, relative molecular mass, glass transition temperature, microstructure, melting temperature, thermal degredation temperature, and weight loss due to collagen thermal degredation influenced by the type of solvent used. The value of TS and elongation at break $(\mathrm{E})$ is influenced by the type of solvent.

\section{References}

[1] -------(1998) NPAG Data: Pomacea canaliculata Golden Apple Snail Molamppc598

[2] AOAC. (1995). "Official Methods of Analysis of The Association of Official Analytical Chemist". Washington DC:Washington Inc.

[3] Bailey, A. J., dan Light, N. D. (1989). "Connective tissue in meat and meat products". London \& New York: Elsevier Applied Science. pp. 238-242.

[4] Bailey, A. J., Paul, R. G. dan Knott, L. (1998). "Mechanisms of maturation and aging of collagen". Mechanism of Aging and Development, 106, 1-56.

[5] Balian, G. dan Bowes, J. H. (1977). The structure and properties of collagen. In A. G. Ward dan A. Courts (Eds.), The science and technology of gelatin (pp. 1-31). London: Academic Press

[6] Bandekar, J. (1992). "Amide modes and protein conformation". Biochimica et Biophysica Acta - Protein Structure and Molecular Enzymology, 1120, 123- 143.

[7] Barreto. P.L.M., Pires. A.T.N., Soldi. V, (2003) "Thermal degradation of edible films based on milk proteins and gelatin in inert atmosphere". Polymer Degradation and Stability, 79, $147-152$.

[8] Barrett, G. C.dan Elmore, D.T. (2004), Amino Acids and Peptides, Cambridge university press, UK.

[9] Blankenship, RE., J.M. Olson and M. Miller. 1995. Antenna complexes from green photosynthetic bacteria. In Blankenship, Madigan and Bauer (Editors), Anoxygenic Photosynthctic Bacteria, Kluwer Academic Publishers, Dordrecht. pp. 399-435.

[10] BSI (British Standards Institution). (1975). Methods for sampling and testing gelatin (physical and chemical methods). London: BSI.

[11] Burdygina. G. I., V. Pron'kina.YE.,. Radugina.YU. YE, Opel'boim. V. V. and KozLov .P. V. (1975), "Effect of low molecular weight substances on the thermal resistance of gelatin",AllUnion Scientific Research Institute of Films 
[12] Doyle, B. B., Bendit, E. G. dan Blout, E. R. (1975). "Infrared spectroscopy of collagen and collagen-like polypeptides". Biopolymers, 14, 937-957.

[13] Estebenet. A L. dan Martínn. P R. (2002) "Pomacea canaliculata (Gastropoda: Ampullariidae): Life-history Traits and their Plasticity" Biocell, 26(1): 83-89

[14] Friess, W. dan Lee, G. (1996). "Basic thermoanalytical studies of insoluble collagen matrices". Biomaterials, 17, 2289-2294.

[15] George, A. dan Veis, A. (1991). "FTIRS in H2O demonstrates that collagen monomers undergo a conformational transition prior to thermal self-assembly in vitro". Biochemistry, $30,2372-2377$.

[16] Gustavson, K. (1956). The chemistry and reactivity of collagen. New York: Academic Press.

[17] Halwart, M. (1994). "The golden apple snail Pomacea canaliculata in Asian rice-farming systems: present impact and future threat". International Journal of Pest Management, 40(2):199-206.

[18] Halwart, M. 1994. The golden apple snail Pomacea canaliculata in Asia rice farming system: Impact and Future Threat. International Journal of Pest Management, 40 (2): 199-206.

[19] Haugstad, G. dan Gladfelter, W.L. (1994). "Probing biopolymers with scanning force methods: Adsorption, structure, properties, and transformation of gelatin on mica". Langmuir, 10, 4295-4306.

[20] Jackson, M., Choo, L., Watson, P. H., Halliday, W. C. dan Mantsch, H. H. (1995). "Beware of connective tissue proteins: Assignment and implications of collagen absorptions in infrared spectra of human tissues". Biochima et Biophysica Acta, 1270, 1-6.

[21] Johnston-Banks, F. A. (1990). "Gelatin”. di P. Harris (Ed.)," Food gels" (hal. 233-289). London: Elsevier Applied Science Publishers.

[22] Jongjareonrak, A., Benjakul, S., Visessanguan, W., Nagai, T., dan Tanaka, M. (2005). "Isolation and characterization of acid and pepsin-solubilised collagens from the skin of Brownstripe red snapper (Lutjanus vitta)".Food Chemistry, 93, 475-484.

[23] Karim, A.A. dan Rajeev Bhat, (2009), "Fish gelatin: properties, challenges, and prospects as an alternative to mammalian gelatins", Food Hydrocolloids 23, 563-576.

[24] Kasankala, L. M., Xue, Y., Weilong, Y., Hong, S. D., dan He, Q. (2007). "Optimization of gelatine extraction from grass carp (Catenopharyngodon idella) fish skin by response surface methodology". Bioresource Technology, 98(17), 3338-3343.

[25] Kasankala, L. M., Xue. Y, Weilong, Y., Hong, S. D. dan He, Q. (2007). "Optimization of gelatine extraction from grass carp (Catenopharyngodon idella) fish skin by response surface methodology". Bioresource Technology, 98(17), 3338-3343.

[26] Langmaier F., Mokrejs P., Kolomaznik K. dan Mladek M. (2008). "Plasticizing collagen hydrolysate with glycerol and low-molecular weight poly(ethylene glycols)". Thermochimica Acta, 469, 52-58.

[27] Lavialle, F., Adams, R. G. dan Levin, I. W. (1982). "Infrared spectroscopic study of the secondary structure of melittin in water, 2-chloroethanol, and phospholipid bilayer dispersions". Biochemistry, 21, 2305-2312.

[28] Liu, H.Y., Han J. dan Guo. S.D. (2009). "Characteristics of the gelatin extracted from Channel Catfish (Ictalurus Punctatus) head bones. LWT - Food Science and Technology, .42, 540-544.

[29] Melnick, S.C. 1958. Occurrence of collagen in the Phylum Mollusca. Nature, London, 181, 1483.

[30] Mizuta, S., Isobe, S. dan Yoshinaka, R. (2002). "Existence of two molecular species of collagen in the muscle layer of the ascidian (Halocynthia roretzi)". Food Chemistry, 79, 913.

[31] Mizuta, S., Miyagi, T., Nishimiya, T., dan Yoshinaka, R. (2002). "Partial characterization of collagen in mantle and adductor of pearl oyster (Pinctada fucata)". Food Chemistry, 79, 319-325. 
[32] MMontero, P. dan Gomez-Guillen, M. C. (2000). "Extracting conditions for megrim (Lepidorhombus boscii) skin collagen affect functional properties of the resulting gelatin". Journal of Food Science, 65(3). 434-438.

[33] Montero, P., Borderias, J., Turnay, J. dan Lizarbe, M. A. (1990). "Characterization of hake (Merluccius merluccius L.) and trout (Salmo irideus Gibb.) collagen". Journal of Agricultural and Food Chemistry, 38, 604-609.

[34] Montero, P., dan Go'mez-Guille'n, M. C. (2000). "Extracting conditions for megrim (Lepidorhombus boscii) skin collagen affect functional properties of the resulting gelatin". Journal of Food Science, 65(3), 434-438.

[35] Norland, R.E. (1997). "Fish Gelatin : Technical Aspects and Applications". London: Royal Photographic Society. 266-281.

[36] Norziah, M.H., Al-Hassan, A., Khairulnizam, A. B., Mordi, M. N., dan Norita, M. (2009). "Characterization of Fish Gelatin from Surimi Processing Waste: Termal Analysis and Effect of Transglutaminase on Jel Properties". FoodHydrocolloid, 23: 1610-1616.

[37] Nuthong, P., Benjakul, S. dan Prodpran, T. (2009). "Characterization of porcine plasma protein-based films as affected by pretreatment and cross-linking agents". International Journal of Biological Macromolecules, 44(2), 143-148.

[38] Pati. F, Basudam Adhikari dan Santanu Dhara. (2010). "Isolation and characterization of fish scale collagen of higher thermal stability", Bioresource Technology, 101, 3737-3742.

[39] Patil, R.D.,Marka, J. E., Apostolovb, A., Vassilevab, E.,dan Fakirovb, S. (2000). "Crystallization of water in some crosslinked gelatins". European Polymer Journal, 36, 1055-1061.

[40] Payne, K.J. dan Veis, A. (1988). "Fourier transform IR spectroscopy of collagen and gelatin solutions: Deconvolution of the Amide I band for conformational studies". Biopolymers, 27, 1749-1760.

[41] Poppe, J. (1997), Gelatin. dalam A . Imeson (Ed.), Thickening and gelling agents for food (pp. 98-123). Glasgow, UK: Blackie Academic and Professional.

[42] Prystupa, D.A. dan Donald, A.M. (1996)."Infrared study of gelatin conformations in the gel and sol states". Polymer Gels and Networks, 4, 87-110.

[43] Renugopalakrishnan, V.; Chandrakasan, G.; Moore, S.; Hutson, T. B.; Berney, C. V.; Bhatnagar, R. S. (1989), Bound water in collagen: evidence from Fourier transform infrared and Fourier transform infrared photoacoustic spectroscopic study. Macromolecules, 22, 4121-4124.

[44] Shen, X.R., Kurihara, H dan Takahashi, K. (2007). "Characterization of molecular species of collagen in scallop mantle", Food Chemistry, 102, 1187-1191.

[45] Shen. X.R, Hideyuki Kurihara, dan Koretaro Takahashi, (2007), "Characterization of molecular species of collagen in scallop mantle", Food Chemistry 102, 1187-1191.

[46] Sinthusamran, Sittichoke, Soottawat Benjakul, and Hideki Kishimura. 2014. Characteristics and Gel Properties of Gelatin from Skin of Seabass (Lates Calcarifer) as Influenced by Extraction Conditions. Food Chemistry 152. Elsevier Ltd: 76-84.

[47] Stainsby, G. (1987). "Gelatin gels". In A. M. Pearson, T. R. Dutson, dan A. J. Bailey (Eds.). "Advances in meat research, collagen as a food", Vol. 4 (pp. 209-222). New York: Van Nostrand Reinhold Company Inc

[48] Taylor, D. dan Sohl, N. (1962). "An outline of gastropod classification”. Malacologia 1:7-32.

[49] Utama, H. (1997). "Gelatin yang bikin heboh". Jurnal Halal LPPOM-MUI, No.18:10-12.

[50] Veis, A. (1964). The Macromolecular Chemistry of Gelatin. New York: Academic Press.

[51] Ward, A. G. dan Courts, A. (1977). The Science and Technology of Gelatin. London: Academic Press.

[52] Xiong, Y. L. (1997). "Structure-function relationships of muscle proteins". In; S. Damodaran dan A. Paraf (Eds.). Food proteins and their applications (pp. 341-392). New York: Marcel Dekker, Inc. 
[53] Yan. M, Li. B, Zhao. X, Ren. G, Zhuang. Y, Hou. H, Zhang. X, Chen. L, Fan. Y, (2008), "Characterization of acid-soluble collagen from the skin of walleye pollock (Theragra chalcogramma)", Food Chemistry, 107, 1581-1586.

[54] Zhou, P., dan Regenstein, J. M. (2004). "Optimization of extraction conditions for pollock skin gelatin”. Journal of Food Science, 69, C393-C398.

[55] Zhou, P., dan Regenstein, J. M. (2005). "Effects of alkaline and acid pretreatments on Alaska pollock skin gelatin extraction". Journal of Food Science, 70, C392-C396.

[56] Zhou, P., Mulvaney, S. J., dan Regenstein, J. M. (2006). "Properties of Alaska pollock skin gelatin: a comparison with tilapia and pork skin gelatins".Journal of Food Science, 71(6), 313-321. 